\title{
Scoping the Need of Mainstreaming Indigenous Knowledge for Sustainable Use of Bioresources in the Indian Himalayan Region
}

\author{
Vikram S. Negi ${ }^{1} \cdot$ Ravi Pathak $^{1} \cdot$ Shinny Thakur ${ }^{1} \cdot$ Ravindra K. Joshi $^{1} \cdot$ Indra D. Bhatt $^{1} \cdot$ Ranbeer S. Rawal $^{1}$
}

Received: 31 March 2021 / Accepted: 20 July 2021

(c) The Author(s), under exclusive licence to Springer Science+Business Media, LLC, part of Springer Nature 2021

\begin{abstract}
Globally, Indigenous Knowledge Systems (IKSs), which have evolved through rigorously tested methods and practices, are a testimony of human intelligence and endurance. The diversity of goods such as food, beverages, herbs, etc., and its associated systems, which form an integral part of modern cuisine and healthcare systems, are deeply rooted in IKS and immensely contributing to overall well-being of mankind. The present study is an attempt to document and understand the contribution of indigenous and local knowledge to biodiversity conservation and management. Appreciation to the value of traditional and indigenous knowledge is globally recognized for their principles of coexistence and sustainable use practices. Past studies indicate a strong relationship between indigenous knowledge and sustainable development goals. This knowledge is valuable not only to dependent communities, but also to the modern world for ensuring food security and human well-being. The documentation of such valuable knowledge is therefore fundamentally essential for mainstreaming and strengthening the discourses on sustainable ecosystem management, and to address the preponderance of poverty among indigenous communities. Amid the changing scenario of consumption and the trend of revisiting nature-based solutions, the IKS hold a tremendous scope of engaging the community people in sustainable harvest and utilization of natural resources.
\end{abstract}

Keywords Indigenous and local knowledge $\cdot$ Indigenous community $\cdot$ Medicinal plants $\cdot$ Wild edible plants $\cdot$ Biodiversity management $\cdot$ Sustainable Development Goals (SDGs)

\section{Introduction}

Conservation of biodiversity faces multipronged challenges, which are increasing with climate change and growing list of threatened species. Environmental perturbations and anthropogenic disturbances call for increased attention to the conservation and sustainable use of bioresources. The Sustainable Development Goals (SDGs) of the UN Agenda 2030 and the agreement on the Aichi Biodiversity Targets (ABT) by the Parties of the Convention on Biological Diversity (CBD) are the encouraging global responses to promote biodiversity conservation (Navarro et al. 2017). Besides the governmental initiatives, there is a large group of people particularly residing in rural and remote areas, i.e.,

Indra D. Bhatt

id_bhatt@yahoo.com

1 Center for Biodiversity Conservation and Management, G.B. Pant National Institute of Himalayan Environment,

Almora, Uttarakhand, India the indigenous and traditional communities, who have been managing and conserving the biodiversity and natural resources for centuries. It is reported that almost $20 \%$ of our planet is home to some 370 million indigenous people, described as 'first' or 'original' people, having a historic and cultural bond with their biodiversity (UNESCO 2016; Karki et al. 2017). Their diverse knowledge is deeply rooted within the environment and cultural cohesion, ensuring sustainable management of natural resources, and environment protection in the changing world (Magni 2017). CBD defines traditional knowledge as 'the knowledge, innovations, and practices of indigenous and local communities around the world'; this knowledge is developed from experience gained over the centuries by trial and error (Gadgil et al. 1993). Furthermore, this knowledge symbolizes mutual relationships between them and their environments, and transferred through generations by cultural transmission (Berkes et al. 2000; Upadhaya et al. 2007). Traditional and indigenous knowledge systems related to biodiversity conservation are fundamental to human life, especially in rural and remote areas across the globe (Langton and Rhea 2005). Traditional knowledge systems 
are thus fundamental to the livelihoods of millions of people. Indigenous people are involved in the management of diverse ecosystem, natural resources, and conservation of biodiversity; a number of success stories on resource management have been reported globally (Langton et al. 2014; Negi and Maikhuri 2013). This knowledge has contributed to sustainable utilization and conservation of biodiversity, including the rare species (Colding et al. 2003; Bisht and Ghildiyal 2007; Gandile et al. 2017; Berkes et al 2000; Irakiza et al. 2016; Upreti and Tewari 2020). The indigenous knowledge systems also play an important role in socioeconomic development of developing countries due to their higher dependency on bioresources and biodiversity (Langton et al. 2009). For example, documentation of traditional biodiversity-related knowledge on the status, uses, and management of biological resources constitutes the People's Biodiversity Registers (PBRs) in India (Langton and Rhea 2005). The documentation is therefore vital for appreciation and protection of this valuable knowledge.

Among the world's mountains, Asia has the largest, highest, and most populated mountain systems-the Himalaya. This region forms a diverse geographic and ecological entity endowed with overwhelming richness, representativeness, and uniqueness of biodiversity (Rawal et al. 2013). Undoubtedly, the Himalayan Biodiversity provides a resource base and ecosystem services that sustain life of millions of people in uplands and billions in down streams (Negi et al. 2019). Within the Himalaya, Indian Himalayan Region (IHR) contributes to a large proportion of the Himalayan biodiversity, and is attributed to the wide variety of bio-physical conditions. IHR comprises two biogeographical zones, i.e., Trans-Himalaya-Tibetan Plateau, and Himalaya. These two zones include seven biogeographical provinces (Rodgers et al. 2002) i.e., Ladakh Mountains (Jammu and Kashmir), Tibetan Plateau (Jammu and Kashmir, Himachal Pradesh, Uttarakhand), Sikkim (Northern Sikkim), North-West (Jammu and Kashmir and Himachal Pradesh), West (Uttarakhand), Central (SikkimDarjeeling Himalaya), and East (Arunachal Pradesh including north-east region). The rich biodiversity in the region is the outcome of conservation and management practices of the local inhabitants. IHR is well recognized for prevalence of Indigenous Knowledge Practices (IKP); these practices have helped them to ensure food security, and play an important role in biodiversity conservation and management (Farooquee et al. 2004; Negi et al. 2010; Laishram et al. 2020).

In the IHR, indigenous knowledge and resource use practice has been passed on through generations. Various cultural and indigenous groups in the region have developed these unique practices, which are mostly a part of their culture. Moreover, biodiversity management and conservation are aggravated by beliefs and culture of these communities; culture is strengthened by their relationship with biodiversity and environment (Negi 2010; Negi et al. 2017; Joa et al. 2018). Nature worship and management through promoting sacred landscape, forests, and groves are excellent examples of in-situ biodiversity conservation by local communities (Sharma and Devi 2014; Singh et al. 2014; Negi et al. 2017; Sigh et al. 2019). This is an effective approach for sustainable management and utilization of biodiversity in climate change scenarios. Therefore, the present study is an attempts to document the indigenous knowledge of natural resource-based communities in the IHR for mainstreaming and strengthening the discourses on sustainable ecosystem management.

\section{Materials and Methods}

The present study is the synthesis of secondary information extracted from available literature related to indigenous knowledge and its arrays. Various research articles, reports, books, book chapters, and proceedings were explored using Google Scholar, ResearchGate, PubMed, Science Direct, and Springer Link. Various Keywords such as 'SDGs', 'traditional knowledge', 'indigenous knowledge', 'traditional knowledge system', 'indigenous knowledge system', 'indigenous and local knowledge' etc. were used for searching the literature. The literature pertaining to Indian Himalayan Region was further used for the synthesis and analysis. A total of 66 studies on the topic with respect to the Indian Himalayan were finally further reviewed for the synthesis of this document.

\section{Results and Discussion}

\section{Role of IKS in Sustainable Forest Management}

Management of biodiversity by indigenous communities is an age-old practice across the globe particularly in the developing countries. The knowledge of phyto-resource use significantly add to conservation of specific species, including the threatened species (Berkes 2007; Negi et al. 2018). Traditional knowledge system and practices are more common in the IHR due to their high dependency on the natural resources. The indigenous communities of the region have developed a symbiotic relationship with nature with a long history of spiritual and cultural heritage (Jaryan et al. 2010; Kala and Sharma 2010; Vidyarthi et al. 2013). Inhabitants of the region have lived in harmony with nature and thereby are protecting and managing the forests and forest resources, ensuring the flow of ecosystem services through traditional ecological knowledge. Indigenous practices of forest management and biodiversity 
Table 1 Some important sacred natural sites in IHR and their characteristics

\begin{tabular}{lllll}
\hline S. No. & Sacred site & State/UT & Area (hectare) & Dominant plant species \\
\hline 1 & Shankaracharya & Jammu \& Kashmir & 138 & Platanusorientalis, Pinus helepansis, Ephedra gerardiana \\
2 & BakhuDevban & Himachal Pradesh & 6.0 & Cedrus deodara, Quercus leucotrichophora \\
3 & Bhujani & Uttarakhand & 12 & Betula utilis, Juniperus indica, Rhododendron campanulatum \\
4 & Sangfa Fu & Uttarakhand & 20 & Juniperus communis, Rhododendron anthopogon \\
5 & Thal Kedar & Uttarakhand & 15 & Quercus leucotricophora, Q. floribunda, Myrica esculenta \\
6 & EncheyMonastry & Sikkim & 1.61 & Cryptomeria japonica, Cupressus torulosa, Toona spp. \\
7 & Langsomepi & Assam & 65 & Areca catechu, Bauhinia scandens, Phyllanthus emblica \\
8 & HeingangMarjing & Manipur & 7.08 & Pinus kesiya, Albizia lucida, Albizia stipulate, Eugenia praecox \\
9 & Khloo Paiu Ram Pyrthai & Meghalaya & 9.0 & Betula alnoides, Fraxinus Floribunda, Elaeocarpusfloribundus \\
10 & Akashi Ganga & Arunachal Pradesh & 8.0 & Altingia excelsa, Artocarpus lakoocha, Artocarpus heterophyllus, Ficus \\
& & & & palmata, Pterosepermum acerifolium
\end{tabular}

Sources: Jamir and Pandey 2003; Khumbongmayum et al. 2005; Negi and Nautiyal 2005; Vasan and Kumar 2006: Anonymous 2010; Agoramoorthy and Kumar 2011; Gokhale and Pala 2011; Negi et al. 2012; Murtem and Chaudhry 2014

conservation involve delineation of sacred forests, sacred groves, and devoted forest patches. This is one of the important practices of conserving forest patches; dedicating forest or forest patch to the local deity automatically conserves the biodiversity in the region (Gadgil and Vartak 1976; Negi and Maikhuri 2013). These are mostly associated with temples and are also culturally important. These sites serve as a refuge to diverse group of floral and faunal biodiversity elements, and hence are important means for conservation and management.

Sacred groves and forests are rich with many rare, endemic, and threatened plant species along with important fauna in the Indian Himalayan Region (Negi and Nautiyal 2005; Rai 2007; Singh et al. 2010; Anthwal et al. 2010; O'Neill et al. 2017; Upadhyay et al. 2019). In IHR more than 5800 sacred groves have been reported, with Himachal Pradesh alone having 5000 sacred groves (Sharma and Kumar 2020; CPREEC ENVIS 2020). In a study from Uttarakhand, Negi et al. (2018) reported unique threatened and endemic species of medicinal plants (MPs) in the sacred groves/forests. One of the best examples of sacred forest is the Tarkeshwar Sacred forest in Uttarakhand, representing 343 plant species of which at least 50 are medicinal plant species (Bisht and Ghildiyal 2007). Hariyali Devi SG is one of the oldest sacred grove in Uttarakhand, well known for rich floral and faunal diversity; around 80 species of plants in 44 families reported having high economic values (Singh et al. 2017). This grove also represent 9 mammals; Capricornis sumatraensis, Cervus unicolor, and Felis bengalensis are some common mammalian species. Tungnath sacred grove is known to harbor threatened MPs like Picrorhiza kurroa and Nardostachys jatamansi. Some endangered animals like musk deer, and Himalayan black bear are also reported from the grove. In Eastern and Northeast region of the IHR, many sacred groves are well known for contributing toward biodiversity conservation attributed to the nature worship tradition of the communities (Khumbongmayum et al. 2005). The sacred groves in five states of north-east India i.e., Arunachal Pradesh, Assam, Manipur, Meghalaya, and Sikkim, covers $>40,000$ hectares of natural forest area (Upadhyay et al. 2019). In Jaintia hills of Meghalaya, there are many sacred groves, however, three sacred groves namely Khloo Paiu Ram Pyrthai, Urkhla, and Khloo Langdoh are of great significance as the species recorded from these groves are $12 \%$ of the flora of the state and $26 \%$ of the flora of Jaintia hills (Jamir and Pandey 2003). In Sikkim, traditional and community knowledge strengthens conservation policies and has paved the way for its adaptive capacity (O'Neill et al. 2017), thus ensuring sustainable forest and biodiversity management. The details of some of the important sacred forest/groves of IHR are presented in Table 1.

Resource use in terms of lopping, felling of trees is strictly prohibited in sacred forests; dead wood or twigs may however be harvested only for the purposes of religious rituals during specific occasions (Negi et al. 2018). Religious sanction of the resources for use purpose from the forest granted in times or in need of people. Thus, sustainable management of forest in Uttarakhand by sacred forests/groves is an important means of conservation and sustainable use of biological diversity; also addressing fundamental objectives of the CBD (Convention on Biological Diversity 2021). Another forest management practice that shows the significant role of IKS, is community forest. Community Forests (Van Panchayat) are the important means of poverty reduction, biodiversity conservation, and ecological sustainability (Agrawal 2007; Newton et al. 2015; Germain et al. 2018; Pandey et al. 2017). Community-based forest management is widely popular in the developing countries indicated by the fact that $31 \%$ of the total forests are being managed by the community themselves in several countries (Wangchuk 
et al. 2018; Maraseni et al. 2019; Gatiso 2019). Most of the earlier studies on community forests at global level (Hayes and Persha 2010; Persha et al. 2011; Porter-Bolland et al. 2012) and regional level (Somanathan 1991; Agarwal 2007; Somanathan et al. 2009; Negi et al. 2012; Thapliyal 2013), suggest that community forestry performs better in management of forests and also maintain sustainable supply of goods to the dependent inhabitant. By formulating a set of rules, indigenous community ensures that the forest under their management fulfill their needs and the community in return helps toward conservation of the forest. Studies have reported that over half a billion people depend on the community-managed forests (Agrawal 2007; Niraula and Pokharel 2016). Traditional practice of managing forest resources in the IHR are most common and vital mean of sustainable resource utilization and conservation. Among other, Uttarakhand is often cited for good management of forests through institutions like Van Panchayat (Agrawal 2007; Negi et al. 2012). The VPs in Uttarakhand are one of the oldest examples of co-management of forest resources by the community themselves. State forest department is managing most of the forests in the state, however, $15 \%$ of the forest is under the control of village community, commonly known as Van Panchayat (VP) or Forest Council (UFS 2018). The example of few well-managed Van Panchayat in Uttarakhand is presented in Table 2.

\section{Role of IKS in Non-timber Forest Products Management}

Global and national markets for Non-timber Forest Products (NTFPs) have been growing rapidly, and significant economic gains are being realized. The natural resource-based communities have strong relationship with forests in the IHR, as forests play an important role in the economy and ecology of the region (Negi et al. 2018). In recent decades, particular attention has been paid to mainstream local biodiversity for food and nutrition security by several UNGA resolutions including World Health Assembly (WHO 2015). It is reported that forest products contribute to the livelihood of millions of people across the globe (Mamo et al. 2007). Reports indicate that wild edibles are used as sources of food in many developing countries, and provide an adequate level of nutrition to human beings (Maikhuri et al. 2004; Murphy et al. 2005). The wide use of nontimber forest products (NTFPs) particularly in the rural/ remote areas totally depends on the indigenous knowledge system. Among other, conservation and sustainable use of medicinal plants (MPs) and wild edibles is receiving increased attention due to their significant role in global healthcare system and nutritional security (Shahidullah and Haque 2015, Chen et al. 2016). The collection of MPs and wild edibles also form a critical source of income in many

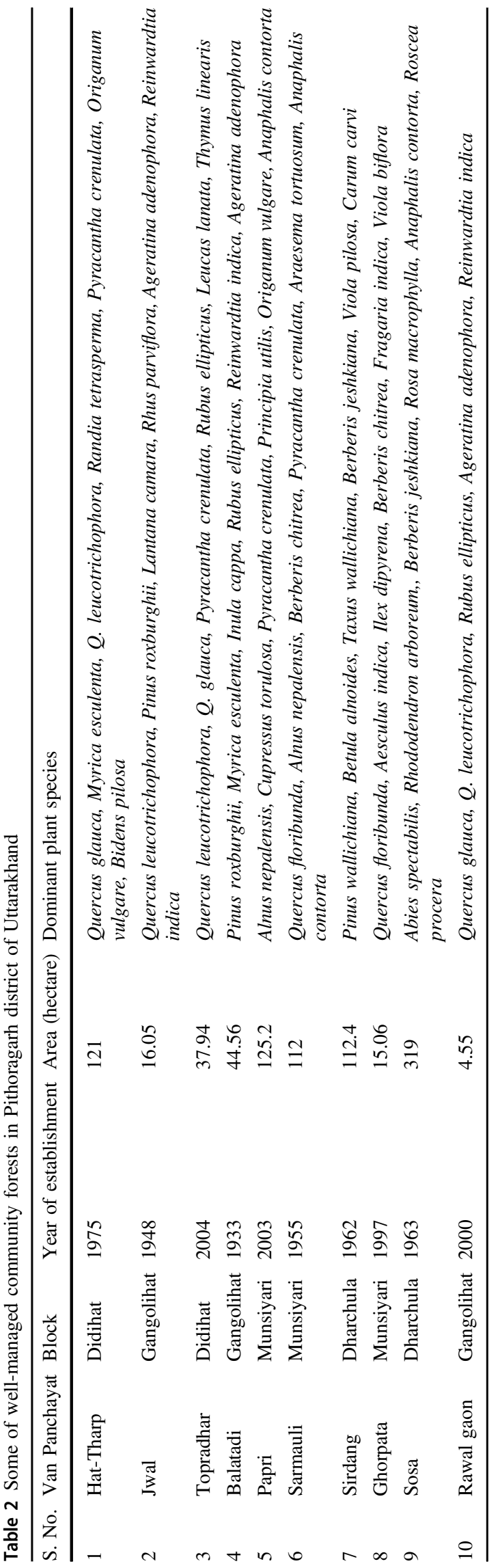


rural and remote areas in the Himalayan region (Maikhuri et al. 2007; Negi et al. 2011; Singh et al. 2021). The indigenous communities have inherited knowledge related to the use of MPs and wild edibles in traditional system of herbal medicine through generations; this has played a key role in the healthcare system and formulation of new drugs across the globe (Nautiyal et al. 2008; Bhatia et al. 2015; Negi et al. 2018).

Wild fruits contribute to diet diversity and flavour, thereby, forming an essential part of nutritionally rich diet of rural people, and provide essential micronutrients (Negi et al. 2011; Bhatt et al. 2017; Aryal et al. 2018; Ray et al. 2020). Further, wild edibles enrich dietary quality of food, and are frequently taken as supplementary nutrition by indigenous communities in the IHR. The wild edibles are not only known for their nutritional value but also for their preventive properties against various diseases (Maikhuri et al. 1994, 2004, 2018; Dhyani et al. 2011; Rawat et al. 2011; Bhatt et al. 2017). The nutritional strength along with medicinal and therapeutically value highlighted the nutraceutical potential of wild resource in meeting the SDGs. Consumption of fruits rich in minerals and nutrients, have been linked with reduced risk of chronic diseases (Bhatt et al. 2013). A number of wild edibles i.e., Hippophae salicifolia (Dhyani et al. 2011), Rhododendron arboreum, Embelica officinalis (Maikhuri et al. 2004; Negi et al. 2011), Myrica esculenta (Bhatt et al. 2000), Spondias axillaris (Sundriyal and Sundriyal 2003), Parkia speciosa, Amorphophallus bulbilfer, and Diplazium esculentum (Deb et al. 2013) have begun to draw attention for being the income-generating avenue; thereby sustainably harvested and managed by the indigenous communities in the IHR. Indigenous communities in many IHR states are harvesting wild edibles for long, with prevailing sense of maintaining ecological integrity. For example, Hippophae rhamnoides in the union territory of Ladakh is sustainably harvested for their culinary and medicinal uses (Stobdan et al. 2017).

Herbal system of medicines is rooted in the indigenous knowledge systems across the globe. Even today with so much of progress in drug industries, the fact remains that 70-95\% population in developing countries still depends on MPs for their primary healthcare (Rawal et al. 2021). In fact, this knowledge made an outstanding contribution to the origin and evolution of many traditional herbal therapies and modern drug formulations (Dhar et al. 2000; Kala 2005; Bhatt et al. 2013). With over 50,000 herbal formulations in the codified medical tradition are known to rural communities in India, and 671,124 registered medical practitioners practicing traditional systems of medicine, and 9000 registered and licensed manufacturing units, India occupies a unique position in traditional system of medicine in the world (Goraya and Ved 2017; Sarkar et al. 2020). MPs in the IHR are reported to contribute significantly toward affordable healthcare in the rural and remote areas (Goraya and Ved 2017; Negi et al. 2018; Singh et al. 2021). The MPs are also known for making various life-saving drugs and provide livelihood options. It is interesting that inspite the majority of old people from the region less educated, but they possess deep understanding and knowledge of traditional healthcare. Sustainable collection practices by indigenous people are significant in conservation of resources and to fulfill their daily need of resources. Rotational harvesting practice is adopted by rural people for collection of MPs; this is important practice for protecting populations of plants in the wild. These practices ensure sustainable supply of MPs and provide incremental benefits to the villagers in and around the forests. Indigenous communities conserve species that are likely to be at most risk from destructive harvesting, to ensure their viable populations in their habitats. MP sector across the globe has received high momentum in view of its potential for the source of raw material of modern therapeutics and precursor molecules for synthesis and preparation of new drugs (Shahidullah and Emdad 2010). The global market for plant-derived drugs was valued US $\$ 1.2$ billion in 1990 s, US $\$ 25.6$ billion in 2015 (Roosta et al. 2017), US\$27.93 billion in 2019 and is projected to reach US $\$ 35.81$ billion by 2027 (Anonymous 2021). With increased global interest in nature-based solutions (NBS) people are looking toward MPs as potential immunity-boosting elements. Amid COVID-19 pandemic situation, the attention on herbal products as immunity booster has grown considerably (Rawal et al. 2021). Understanding market-driven economy, indigenous communities are now cultivating MPs to meet the raw material demand; this is automatically conserving the wild resources. For example, Picrorhiza kurrooa, Sassurea costus, Valeriana jatamansi, Innula racemosa, Allium stracheyi, Arnebia benthamii, Bergenia stracheyi, Rosmarinus officinalis, Asparagus racemosus, Cinnamomum tamala, Aconitum heterophyllum, Angelica glauca, and Swertia chirata are important MPs that are being cultivated in different parts of IHR (Kuniyal et al. 2005; Samant et al. 2007; Maikhuri et al. 2017; Negi et al. 2010, 2018), thus creating enormous opportunity for economic gains through nutraceutical and pharmaceutical sectors. Hence, protection of the genetic pool is urgently required for long-run sustainability and making it available for future generations.

\section{Role of IKS in Conserving Traditional Agro- biodiversity}

Traditional farming systems are the original method of farming practiced by traditional farmers from generation to generation. These practices develop a balance between meeting our present needs and the needs of future generations. Indigenous knowledge practices of agriculture and 
seed conservation thus are important for agrodiversity in the region (Maikhuri et al. 1997, 2001). Indigenous biodiversity-related knowledge is of great significance to food security in the region; reflected by a huge diversity of crops/landraces in diverse farming systems across IHR (Negi and Maikhuri 2013). The farmers ensure adequate supply of organic inputs to their fields from the surrounding forests. This system of nature-based farming has evolved and flourished over millennia following trial and error approach. The traditional methods of maintaining seed stock and cultivars have been critical for sustenance of indigenous people in the region and play an important role in in situ conservation. For example, farmers of Central Himalaya grow about 170 varieties of kidney beans, 100 varieties of paddy, 8 varieties of wheat, and more than 12 varieties of pulses each year in the traditional mixed farming system (Rao et al. 2005; Saxena et al. 2005). Uttarakhand in west Himalaya harbors over 40 different crop species and hundreds of their local cultivars, grown and conserve through a variety of crop composition and crop rotations along wide altitudinal transect (Semwal and Maikhuri 2015). Agrodiversity maintained by the indigenous knowledge system plays a significant role in (i) increasing productivity per unit area, (ii) improving soil fertility by incorporating legumes, (iii) minimizing crop loss to insect pest attacks, (iv) increasing productivity per unit area, (v) providing diversity to food, (vi) conserving soil erosion, and (vii) insurance against absolute crop failure (Semwal and Maikhuri 2015).

The cropping patterns in the western Himalaya are built around two major cropping seasons viz. Kharif (April-October) and Rabi (October-April). Mixed cropping (commonly known as Baranaja) of millet and pseudo-millet with grain legumes and some vegetables in Uttarakhand is a common and unique practice of in situ seed conservation, maximizing yield per unit area (Maikhuri et al. 2001; Nautiyal et al. 2008; Negi et al. 2012). The advantage of mixed cropping is that it ensures yield even if one of the crops fails due to any reason (Zardhari 2000; Maikhuri et al. 1997, 2001; Nautiyal et al. 2008; Negi and Maikhuri 2013). Furthermore, crop rotation and mixed farming is an important feature to maintain soil fertility in the traditional agroecosystem (Sen 1997; Maikhuri et al. 2001). In the North-East Himalaya, the rural forestry management practices and the agriculture-forestry inter-phase linkages of Apatani peoples of Arunachal Pradesh are examples of their nature-culture interconnections (Rai 2007). The traditional wet rice cultivation of the Apatani peoples is an example of sustainable agriculture as it ensures and maintains sustainable productivity (Rai 2005). The agro-ecosystems in North-East Himalaya are sustainable, self-sufficient, and efficient due to strong organizations and sharing of ecological knowledge among farmers from generation to generation. Indigenous classification of agricultural land use into seven different categories for efficient land management is an example of innovative ecological design by the farmer groups in North-East Himalaya (Dollo et al. 2009). Among others, terrace system of cultivation and Bamboo drip irrigation system in Meghalaya, and ZABO system and Alder based agriculture in Nagaland are important traditional systems of agriculture. Thus, indigenous people are not only the custodians but also managers of crop diversity; the key elements of sustainable agricultural system in the IHR.

\section{Biodiversity Act in Ensuring Biodiversity Management and ABS for Local Peoples}

The foundation of international environmental law was laid with the United Nations Stockholm Conference on the Human Environment in 1972, wherein the United Nations Environment Programme (UNEP) was established (Jeffery 2008). The Earth Summit of Rio de Janeiro, also known as the United Nations Conference on Environment and Development (UNCED), resulted in the Convention on Biodiversity, a multilateral treaty, which entered into force on December 1993 (Jeffery 2008). India enacted its own national legislation to fulfill its commitment agreed under the CBD. The Biological Diversity Act, 2002 aimed at the conservation of biodiversity in the country, sustainable utilization of the components of biodiversity, and equitable sharing of benefits arising out of the biological resources and the associated traditional knowledge. Regulation of access to the nation's biological resources and traditional knowledge through the Biological Diversity Act, 2002 can prevent misuse and appropriation of these resources and knowledge through patents on intellectual property rights (IPR). The Biodiversity Act in India has established a threetier structure for implementation. The National Biodiversity Authority (NBA) is responsible for all matters at the national level, and the State Biodiversity Board (SBBs) is responsible at the state level through the formation of Biodiversity Management Committees (BMCs). The NBA provides technical assistance and guidance to the SBBs and BMCs for sustainable use of its biodiversity, fair and equitable sharing of benefits arising out of their utilization. BMC regularly assists the SBBs and the NBA in matters of access and benefit-sharing related to the local biological resources and traditional knowledge through preparing People's Biodiversity Registers (PBRs). The NBA and SBBs consult BMCs while granting approval for access to biological resources or associated knowledge sought by the researchers or companies. In India, preparation of PBRs for the villages has been undertaken in a few states, i.e., Kerala and Uttarakhand earlier, but as per the recent update (April 2021) on website of NBA, 248,156 PBRs have been 


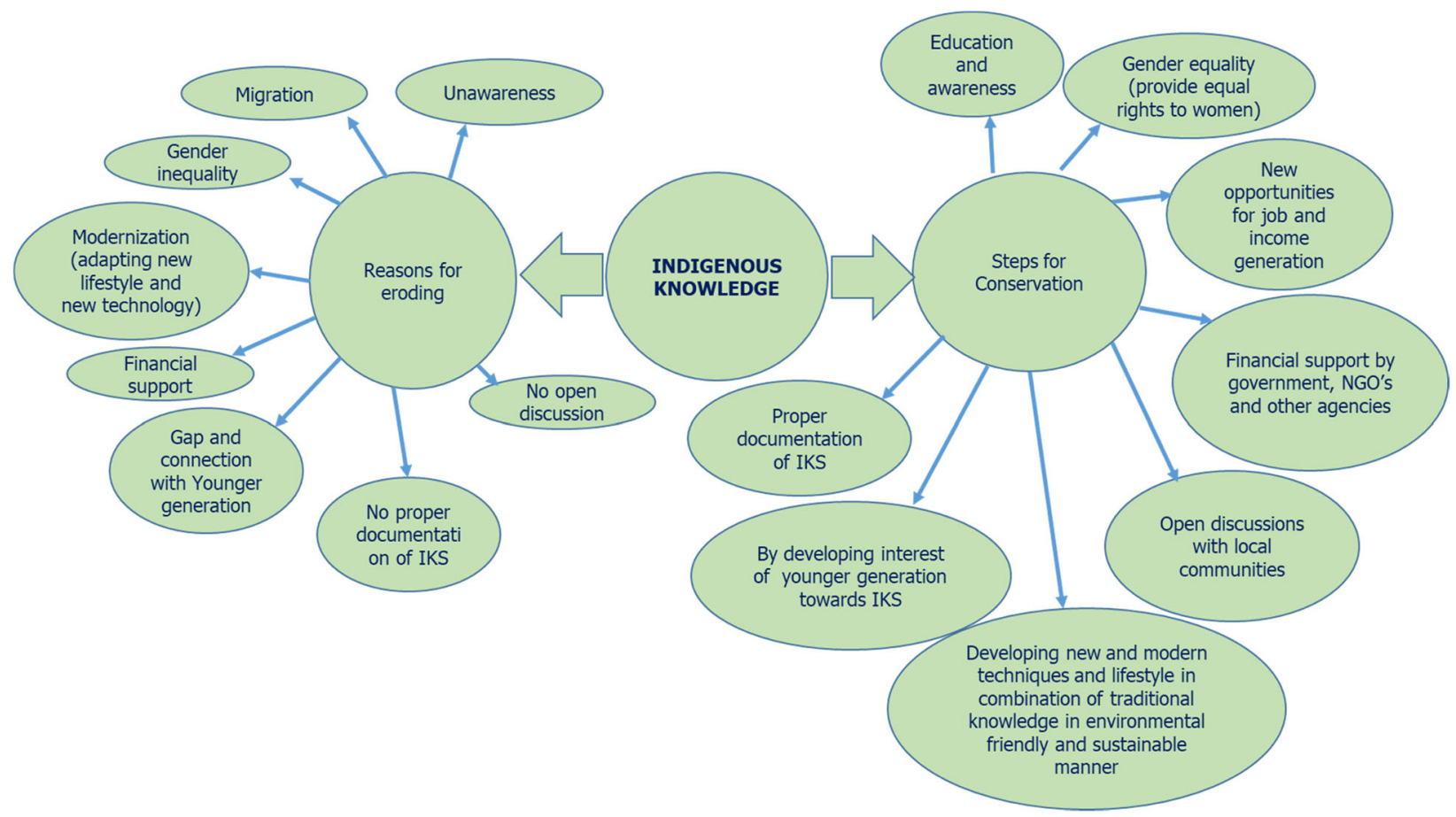

Fig. 1 Steps toward conservation of indigenous knowledge

prepared in all the 28 states and 3 union territories (i.e., Andaman \& Nicobar islands, Jammu \& Kashmir, and Lakshadweep). In particular, section 36(iv) of the Indian Biodiversity Act 2002 provides for the protection of traditional knowledge through knowledge/biodiversity registers. Sections 19 and 21 of the Biodiversity Act require prior approval from NBA to access the resources, which ensure equitable sharing of benefits. Section 6 provides intellectual property rights on research-based needs to obtain prior approval from the NBA.

\section{Role of IKS in Gender Inclusiveness}

In indigenous communities, women and elders play a special role (Ramphele 2004); they are not only the main caregivers, but also the custodians of traditional knowledge, culture, and biological diversity (Negi and Rawat 2010). Women in mountain are naturally more familiar and concerned for biodiversity use and its conservation because of their close association and connection with the surroundings. Women in the Himalayan region work harder and for longer hours than men, and have a vital role in ecosystem management (Negi and Rawat 2010). They hold extensive traditional knowledge related to forest management and agricultural practices (Howard 2003; Chambers and Momsen 2007; Abdelali-Martini et al. 2008); women and elders are considered as primary holders and communicators of traditional knowledge (Magni 2017). Women in the IHR always play a significant role in managing and operating most of the household and agricultural activities (Maikhuri et al. 2011). However, the gender dynamics and their roles in biodiversity conservation are complicated and debatable. For example, in Uttarakhand, there are four reserved seats in the forest council (van panchayat) out of the nine committee members. However, we did not found any female members in most of these committees during field visits in Pithoragarh district. Few studies (Schmink and Gómez-García 2015; Germain et al. 2018) reported male always underestimate the knowledge of women. Our field-based studies also indicated that women are not able to contribute much in decision-making (Thakur et al. 2020). In developing countries like India and Nepal, participation of women is mostly passive (Chhetri et al. 2013; Thapliyal 2013). Pant and Pandey (2007) reported that women were indulged in most of the household activities and community work, however, they are less appreciated in any committees in the villages and any type of decision-making process. The CBD clearly mentions the role of women for sustainable use and conservation of biodiversity, but the role of women in policy-making is still underestimated. Still there is limitation on evidence-based and empirical studies on gender dimensions. There is a need to highlight the role and contribution of women in biodiversity conservation and recognize their participation at all levels of policy-making and decisions (Howard 2003; Oakley and Momsen 2007). Many studies reported that $80-90 \%$ of the seed 


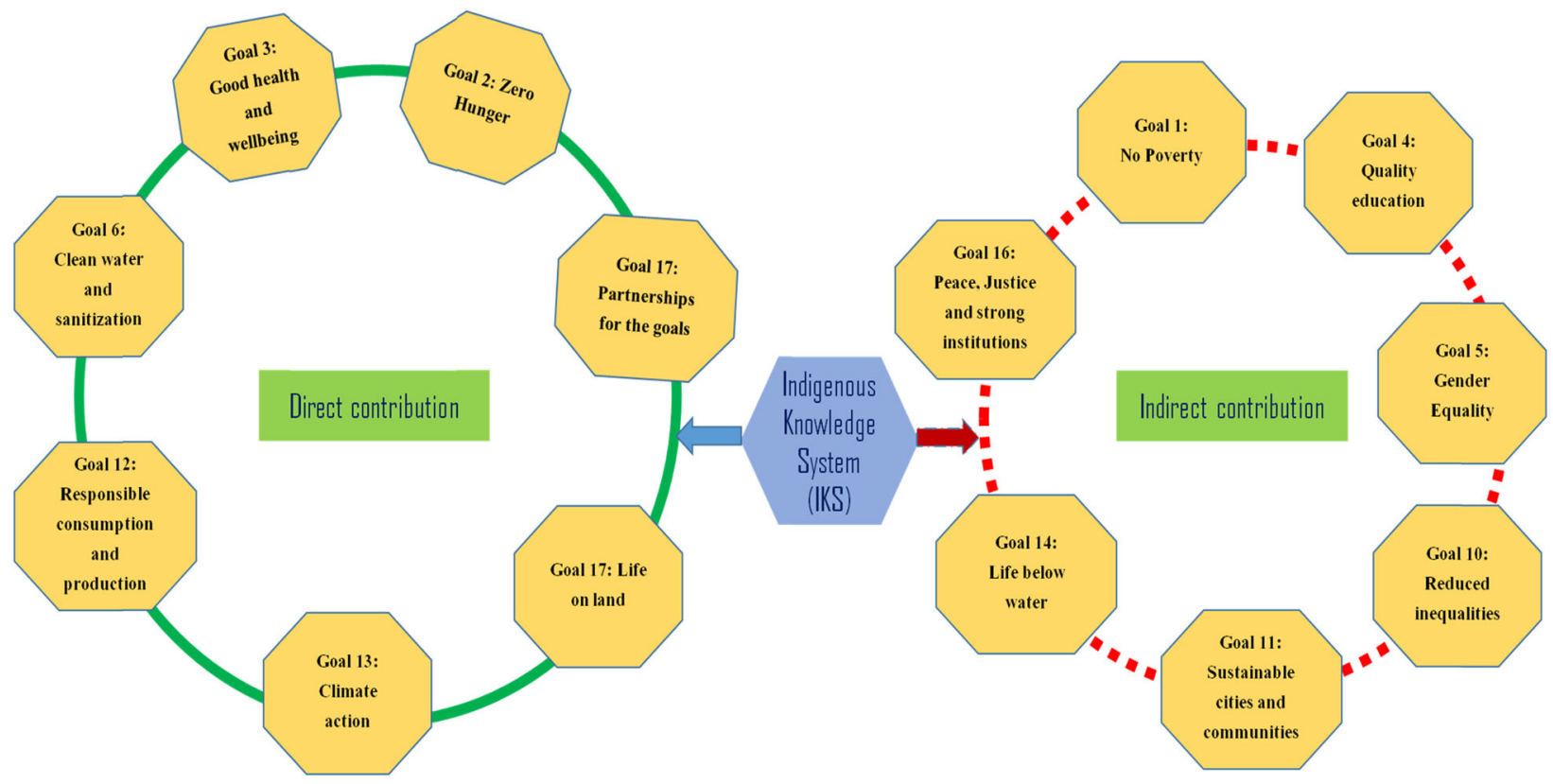

Fig. 2 Contribution of IKS toward achieving Sustainable Development Goals (SDGs)

requirements were met through indigenous seed management and exchange practices, in which women plays the crucial role (Aumeeruddy-Thomas and Shengji 2003). Therefore, gender inclusiveness, especially inclusion of women in resource management and conservation, needs to be ensured (Fig. 1).

\section{Contribution of IKS toward Global Obligations (SDG's)}

The global obligations of sustainable development (The 2030 agenda for sustainable development), as adopted by all United Nations Member States, is envisaged to provide the road map for peace and prosperity of people and the planet in the present as well as in the future. The focus of the agenda is to achieve the 17 goals of sustainable development, i.e., SDGs, by both, developed and developing countries, in concurrence. Toward achieving these sustainability goals, the role of Indigenous people becomes putative. Indigenous people constitutes $<5 \%$ of the total world's population, and manages $28 \%$ of the world's land surface, which makes them the actual guardians of $80 \%$ of the known global biodiversity (Jerez 2021). Indigenous people across the globe have a wide range of knowledge systems for natural resource management varying with geographical and climate regime. This knowledge is complex, complete, dynamic, and practical having scientific validition (Battiste 2005; Bates et al. 2009; Sillitoe 1998). The traditional methods of resource management applied by the indigenous people have often proven their resilience and sustainability in the face of environmental changes. These traditional methods and knowledge systems ensure the sustainability of the resources, as these resources are vital for subsistence of the indigenous people. The indigenous knowledge systems are being recognized to embrace most of the dimensions of SDGs toward achieving the goals. The indigenous knowledge on MPs plays a crucial role in ensuring healthy living and well-being. This is evident from the current pandemic of COVID-19, wherein the role of MPs in treating the infectious viral disease is realized and recognized (Vandebroek et al. 2021). Similarly, IKS contributes toward achieving SDGs like Quality education (through promoting lifelong learning opportunities), No poverty (providing livelihood options), Zero hunger (ensuring food security through sustainable agricultural practices), clean water, and sanitization (through spring management), and many more (Fig. 2). All these contributions of IKS thus ensure the sole purpose of the 2030 agenda for achieving sustainable development.

\section{Conclusion}

The current method and pace of development have contributed irreversible and irreparable harm to natural resources and diminished capacities of ecosystems to emanate goods and services. Further, the contemporary use practices, often exploitive in nature have been emerging as a new way of living and transcending across various cultural ethnic boundaries. The efforts of mainstreaming people without their knowledge have further speed up the process of homogenization, thus leaving our systems more 
vulnerable to further exploitation and degradation. Indigenous knowledge, which has evolved in consonance with natural surroundings, climatic perturbations, and is often based on the principle of coexistence and communitarianism is rather overlooked and considered obsolete in conservation planning and management. The skills and techniques of indigenous people provide valuable information to the global community and a useful model for biodiversity policies. Research has demonstrated that participatory approaches are key to ensure the right and balanced representation of different knowledge systems, particularly of traditional and scientific knowledge. The success of IKS when economies were closed and people were interdependent needs to be duly appreciated by affecting the mainstreaming of their knowledge as well as exploring its possibilities of upscaling.

Acknowledgements The authors are grateful to the Director GBPNIHE for providing facilities. Partial funding from GBP-NIHE Inhouse Project-4 on 'Mainstreaming Himalayan Biodiversity for Sustainable Development', and ICIMOD, Kathmandu under KSLCDIII is greatly acknowledged.

\section{Compliance with Ethical Standards}

Conflict of Interest The authors declare no competing interests.

Publisher's note Springer Nature remains neutral with regard to jurisdictional claims in published maps and institutional affiliations.

\section{References}

Abdelali-Martini M, Amri A, Ajlouni M, Assi R, Sbieh Y, Khnifes A (2008) Gender dimension in the conservation and sustainable use of agro-biodiversity in West Asia. J Socio-Econ 37(1):365-383

Agarwal B (2007) Gender inequality, cooperation and environmental sustainability. Inequality, cooperation and environmental sustainability. Princeton University Press, Princeton, New Jersey, p 274-313

Agoramoorthy G, Kumar VV (2011) The Shankaracharya sacred grove of Srinagar, Kashmir, India. Curr Sci 101(3):262

Anonymous (2010) Sacred groves of Sikkim. Sikkim Forest Department. http://www.sikkimforest.gov.in/Reports\%20and\%20Publications/Sa credGroves/Sacred\%20Grooves\%20of\%20Sikkim $\% 202011 \%$ 20Edition\%20FEWMD.pdf

Anonymous (2021) Botanical and plant derived drugs market size in 2021 (new report): manufacturers data, opportunity, import export scenario, application, type, regions and future forecast till 2027 with top growth companies. https://www.marketwatch.com/ press-release/botanical-and-plant-derived-drugs-market-size-in2021-new-report-manufacturers-data-opportunity-import-exportscenario-application-type-regions-and-future-forecast-till-2027-w ith-top-growth-companies-2021-03-24

Anthwal A, Gupta N, Sharma A, Anthwal S, Kim KH (2010) Conserving biodiversity through traditional beliefs in sacred groves in Uttarakhand Himalaya, India. Resour, Conserv Recycling 54(11): 962-971

Aryal KP, Poudel S, Chaudhary RP, Chettri N, Chaudhary P, Ning W, Kotru R (2018) Diversity and use of wild and non-cultivated edible plants in the Western Himalaya. J Ethnobiol Ethnomed 14(1):1-18

Aumeeruddy-Thomas Y, Shengji P (2003) Applied ethnobotany: casestudies from the Himalayan region. WWF

Bates P, Chiba M, Kube S, Nakashima D (2009) Learning \& Knowing in Indigenous Societies Today. UNESCO

Battiste M (2005) Indigenous knowledge: foundations for first nations. WINHEC: Int J Indigenous Educ Scholarsh 1(1):1-7

Berkes F (2007) Community-based conservation in a globalized world. Proc Natl Acad Sci 104(39):15188-15193

Berkes F, Colding J, Folke C (2000) Rediscovery of traditional ecological knowledge as adaptive management. Ecol Appl 10 (5):1251-1262

Bhatia H, Sharma YP, Manhas RK, Kumar K (2015) Traditional phytoremedies for the treatment of menstrual disorders in district Udhampur, J\&K, India. J Ethnopharmacol 160:202-210

Bhatt ID, Rawal RS, Dhar U (2000) The availability, fruit yield, and harvest of Myrica esculenta in Kumaun (west Himalaya), India. Mt Res Dev 20(2):146-153

Bhatt ID, Rawat S, Badhani A, Rawal RS (2017) Nutraceutical potential of selected wild edible fruits of the Indian Himalayan region. Food Chem 215:84-91

Bhatt ID, Rawat S, Rawal RS (2013) Antioxidants in medicinal plants. In: Biotechnology for medicinal plants. Springer, Berlin, Heidelberg, p 295-326

Bisht S, Ghildiyal JC (2007) Medicinal plant diversity within Tarkeshwar Sacred Grove in Gahrwal Himalaya. Envis Forestery Bull (Medicinal Plants Spec) 7(2):40-45

Chambers KJ, Momsen JH (2007) From the kitchen and the field: gender and maize diversity in the Bajio region of Mexico. Singap J Tropical Geogr 28(1):39-56

Chen SL, Yu H, Luo HM, Wu Q, Li CF, Steinmetz A (2016) Conservation and sustainable use of medicinal plants: problems, progress, and prospects. Chin Med 11(1):1-10

Chhetri BBK, Johnsen FH, Konoshima M, Yoshimoto A (2013) Community forestry in the hills of Nepal: determinants of user participation in forest management. For Policy Econ 30:6-13

Colding J, Folke C, Elmqvist T (2003) Social institutions in ecosystem management and biodiversity conservation. Tropical Ecol 44 (1):25-41

CPREEC ENVIS (2020) Sacred Groves of India. http://ecoheritage. cpreec.org/innerpageof.php?\$mFJyBfKPkE6. Accessed 10.04.2021

Deb D, Sarkar A, Debbarma B, Datta BK, Majumdar K (2013) Wild edible plants and their utilization in traditional recipes of Tripura, Northeast India. Adv Biol Res 7(5):203-211

Dhar U, Rawal RS, Upreti J (2000) Setting priorities for conservation of medicinal plants - a case study in the Indian Himalaya. Biol Conserv 95(1):57-65

Dhyani D, Maikhuri RK, Dhyani S (2011) Seabuckthorn: an underutilized resource for the nutritional security and livelihood improvement of rural communities in Uttarakhand Himalaya. Ecol Food Nutr 50(2):168-180

Dollo M, Samal PK, Sundriyal RC, Kumar K (2009) Environmentally sustainable traditional natural resource management and conservation in Ziro Valley, Arunachal Himalaya, India. J Am Sci $5(5): 41-52$

Farooquee NA, Majila BS, Kala CP (2004) Indigenous knowledge systems and sustainable management of natural resources in a high altitude society in Kumaun Himalaya, India. J Hum Ecol 16(1):33-42

Ford JD, Pearce T, Duerden F, Furgal C, Smit B (2010) Climate change policy responses for Canada's Inuit population: the importance of and opportunities for adaptation. Glob Environ Change 20(1):177-191

Gadgil M, Berkes F, Folke C (1993) Indigenous knowledge for biodiversity conservation. Ambio 22(2/3):151-156 
Gadgil M, Vartak VD (1976) The sacred groves of Western Ghats in India. Economic Bot 30(2):152-160

Gandile AU, Tessema SM, Nake FM (2017) Biodiversity conservation using the indigenous knowledge system: The priority agenda in the case of Zeyse, Zergula and Ganta communities in Gamo Gofa Zone (Southern Ethiopia). Int J Biodivers Conserv 9(6):167-182

Gatiso TT (2019) Households' dependence on community forest and their contribution to participatory forest management, evidence from rural Ethiopia. Environ, Dev Sustainability 21(1):181-197

Germain R, Ghosh C, Jayasuriya M (2018) Community forestry in the state of Uttarakhand, India, not meeting the needs of the villagers. Small-scale Forestry 17(2):225-242

Gokhale Y, Pala NA (2011) Ecosystem services in sacred natural sites (SNSs) of Uttarakhand: a preliminary survey. J Biodivers 2(2):107-115

Goraya GS, Ved DK (2017) Medicinal plants in India: an assessment of their demand and supply. National Medicinal Plants Board, Ministry of AYUSH, Government of India, New Delhi and Indian Council of Forestry Research and Education, Dehradun

Hayes T, Persha L (2010) Nesting local forestry initiatives: Revisiting community forest management in a REDD + world. For Policy Econ 12(8):545-553

Howard PL (2003) Women and plants: gender relations in biodiversity management and conservation. Zed Books

Irakiza R, Vedaste M, Elias B, Nyirambangutse B, Serge NJ, Marc N (2016) Assessment of traditional ecological knowledge and beliefs in the utilisation of important plant species: the case of Buhanga sacred forest, Rwanda. Koedoe 58(1):1-1

Jamir SA, Pandey HN (2003) Vascular plant diversity in the sacred groves of Jaintia Hills in Northeast India. Biodivers Conserv 12(7):1497-1510

Jaryan V, Uniyal SK, Singh RD, Lal B, Kumar A, Sharma V (2010) Role of traditional conservation practice: highlighting the importance of Shivbari sacred grove in biodiversity conservation. Environmentalist 30(2):101-110

Jeffery MI (2008) Biodiversity conservation in the context of sustainable human development: a call to action. In: Biodiversity conservation, law + livelihoods: bridging the north-south divide. Cambridge University Press, pp 69-93

Jerez MM (2021) Challenges and opportunities for Indigenous Peoples' sustainability. https://www.un.org/development/desa/dspd/ 2021/04/indigenous-peoples-sustainability/

Joa B, Winkel G, Primmer E (2018) The unknown known-a review of local ecological knowledge in relation to forest biodiversity conservation. Land Use Policy 79:520-530

Kala CP (2005) Indigenous uses, population density, and conservation of threatened medicinal plants in protected areas of the Indian Himalayas. Conserv Biol 19(2):368-378

Kala M, Sharma A (2010) Traditional Indian beliefs: a key toward sustainable living. Environmentalist 30(1):85-89

Karki M, Hill R, Xue D, Alangui X, Ichikawa K, Bridgewater P (eds) (2017) Knowing our lands and resources: indigenous and local knowledge and practices related to biodiversity and ecosystem services in Asia. Knowledges of Nature 10. UNESCO, Paris, p 212

Khumbongmayum AD, Khan ML, Tripathi RS (2005) Sacred groves of Manipur, northeast India: biodiversity value, status and strategies for their conservation. Biodivers Conserv 14(7):1541-1582

Kuniyal CP, Rawat YS, Oinam SS, Kuniyal JC, Vishvakarma SC (2005) Kuth (Saussurea lappa) cultivation in the cold desert environment of the Lahaul valley, northwestern Himalaya, India: arising threats and need to revive socio-economic values. Biodivers Conserv 14(5):1035-1045

Laishram J, Saxena KG, Rao KS (2020) Rice cultivar diversity, associated Indigenous knowledge and management practices in a lowland village landscape from north-eastern India. Vegetos 33(1):172-186
Langton M, Ma Rhea Z, Sykes H (2009) Indigenous education and the ladder to prosperity. Perspectives. Future Leaders. 95-119. https://d1wqtxts1xzle7.cloudfront.net/30957999/Langton_Ma Rhea-with-cover-page-v2.pdf?Expires $=1625653095 \&$ Signature $=$ ffjpokYfo rYK1IvrOv2y54qPGQOrgFdhYO1GBQMBzWzlX7q5g KZqTCLwywYvOVz0LzRFMFVeaB6NmW1VmrFM bszcgKX0 NNQmzVXJ3oRIBsIUDRjYvPBFC0BwgNIT52FwBBDJQfqb O4c1pUJyEqrVGYgFV-SQCgOLnnWz-Iinl3xk2chUi pLIUj4MIHX5P0x3dgZC47rLBgazS0KvB -1KSkfWM9Pz9CLb FHThSTH4Os7WqWd7qKFQOMGNUvO61kv b-GMmsuByjw v0eCKGU-qY VTOv58P28tleJMk4H 1U15yQ0ffdTqIACTw DOU8rd6FhgmLES-WsnzInBRA_\&Key-Pair-Id= APKAJLOHF5GGSLRBV4ZA. Accessed on March 2021

Langton ML, Palmer L, Ma Rhea Z (2014) Community-oriented protected areas for indigenous peoples and local communities: Indigenous protected areas in Australia. In: Stevens S (ed) Indigenous Peoples, National Parks, and Protected Areas. A new paradigm linking conservation, culture, and rights. The University of Arizona Press, pp 84-107

Langton M, Rhea ZM (2005) Traditional indigenous biodiversityrelated knowledge. Aust Academic Res Libraries 36(2):45-69

Magni G (2017) Indigenous knowledge and implications for the sustainable development agenda. Eur J Educ 52(4):437-447

Maikhuri RK, Negi V, Rawat LS, Purohit VK (2007) Promoting value addition in potential wild edibles of central Himalaya for sustainable livelihood and small scale enterprise development. GB Pant Institute of Himalayan Environment and Development, Almora, India, p. 38

Maikhuri RK, Phondani PC, Dhyani D, Rawat LS, Jha NK, Kandari LS (2018) Assessment of climate change impacts and its implications on medicinal plants-based traditional healthcare system in Central Himalaya, India. Iran J Sci Technol, Trans A: Sci 42(4):1827-1835

Maikhuri RK, Phondani PC, Rawat LS, Jha NK, Maletha A, Bahuguna YM, Kandari LS (2017) Conservation and management strategies of medicinal plant resources through action research approaches in Indian Himalaya. Iran J Sci Technol, Trans A: Sci 41(3):771-777

Maikhuri RK, Rao KS, Saxena KG (2004) Bioprospecting of wild edibles for rural development in the central Himalayan mountain of India. Mt Res Dev 24:110-113

Maikhuri RK, Rao KS, Semwal RL (2001) Changing scenario of Himalayan agroecosystems: loss of agrobiodiversity, an indicator of environmental change in Central Himalaya, India. Environmentalist 21(1):23-39

Maikhuri RK, Rawat LS, Negi VS, Faroouquee NA, Rao KS, Purohit VK, Agarwal SK, Chamoli KP, Negi CS, Saxena KG (2011) Empowering rural women in agro-ecotechnologies for livelihood improvement and natural resource management: A case from Indian Central Himalaya. Outlook Agriculture 40(3):229-236

Maikhuri RK, Semwal RL, Rao KS, Nautiyal S, Saxena KG (1997) Eroding traditional crop diversity imperils the sustainability of agricultural systems in Central Himalaya. Curr Sci 73:777-782

Maikhuri RK, Semwal RL, Singh A, Nautiyal MC (1994) Wild fruit as a contribution to sustainable rural development: a case study from the Garhwal Himalaya. Int J Sustain Dev World Ecol 1:56-68

Mamo G, Sjaastad E, Vedeld P (2007) Economic dependence on forest resources: a case from Dendi District. Ethiop Policy Econ 9(8):916-927

Maraseni TN, Bhattarai N, Karky BS, Cadman T, Timalsina N, Bhandari TS, Apan A, Ma HO, Rawat RS, Verma N, San SM (2019) An assessment of governance quality for communitybased forest management systems in Asia: prioritization of governance indicators at various scales. Land Use Policy 81:750-761

Murphy IK, Bhat PR, Ravindranah NH, Sukumar R (2005) Financial valuation of non-timber forest product flows in Uttara Kannada District, Western Ghats, Karnataka. Curr Sci 10(25):1573-1579 
Murtem G, Chaudhry P (2014) Sacred groves of Arunachal Pradesh: traditional way of biodiversity conservation in Eastern Himalaya of India. J Biodivers Manag Forestry 3:2

Nautiyal S, Bisht V, Rao KS, Maikhuri RK (2008) The role of cultural values in agrobiodiversity conservation: a case study from Uttarakhand, Himalaya. J Hum Ecol 23(1):1-6

Navarro LM, Fernández N, Guerra C, Guralnick R, Kissling WD, Londoño MC, Muller-Karger F, Turak E, Balvanera P, Costello MJ, Delavaud A (2017) Monitoring biodiversity change through effective global coordination. Curr Opin Environ sustainability 29:158-169

Negi BS, Chauhan DS, Todaria NP (2012) Administrative and policy bottlenecks in effective management of Van Panchayats in Uttarakhand. India Law Env't Dev J 8:141

Negi CS (2010) Traditional culture and biodiversity conservation: examples from Uttarakhand, Central Himalaya. Mt Res Dev 30 (3):259-265

Negi CS, Nautiyal S (2005) Phyto-sociological studies of a traditional reserve forest-Thal Ke Dhar, Pithoragarh, Central Himalayas (India). Indian Forester 131(4):519-534

Negi VS, Kewlani P, Pathak R, Bhatt D, Bhatt ID, Rawal RS, Sundriyal RC, Nandi SK (2018) Criteria and indicators for promoting cultivation and conservation of medicinal and aromatic plants in Western Himalaya, India. Ecol Indic 93:434-446

Negi VS, Maikhuri RK (2013) Socio-ecological and religious perspective of agrobiodiversity conservation: issues, concern and priority for sustainable agriculture, Central Himalaya. J Agric Environ Ethics 26(2):491-512

Negi VS, Maikhuri RK, Maletha A, Phondani PC (2019) Ethnobotanical knowledge and population density of threatened medicinal plants of Nanda Devi Biosphere Reserve, Western Himalaya, India. Iran J Sci Technol, Trans A: Sci 43(1):63-73

Negi VS, Maikhuri RK, Phondani PC, Rawat LS (2010) An inventory of indigenous knowledge and cultivation practices of medicinal plants in Govind Pashu Vihar Wildlife Sanctuary, Central Himalaya, India. Int J Biodivers Sci, Ecosyst Serv Manag 6(3-4):96-105

Negi VS, Maikhuri RK, Rawat LS (2011) Non-timber forest products (NTFPs): a viable option for biodiversity conservation and livelihood enhancement in central Himalaya. Biodivers Conserv 20 (3):545-559

Negi VS, Maikhuri RK, Rawat LS (2012) Paradigm and ecological implication of changing agricultural land-use: a case study from Govind Wildlife Sanctuary, Central Himalaya, India. J Mt Sci 9 (4):547-557

Negi VS, Pathak R, Rawal RS, Bhatt ID, Sharma S (2019) Long-term ecological monitoring on forest ecosystems in Indian Himalayan Region: criteria and indicator approach. Ecol Indic 102:374-381

Negi VS, Pathak R, Sekar KC, Rawal RS, Bhatt ID, Nandi SK, Dhyani PP (2018) Traditional knowledge and biodiversity conservation: a case study from Byans Valley in Kailash Sacred Landscape, India. J Environ Plan Manag 61(10):1722-1743

Negi VS, Rawat LS (2010) Work participation and Role of Gender in Village Ecosystem, Central Himalaya, India. We Int J Sci Tech 5:137-146

Newton P, Schaap B, Fournier M, Cornwall M, Rosenbach DW, DeBoer J, Whittemore J, Stock R, Yoders M, Brodnig G, Agrawal A (2015) Community forest management and REDD+. For Policy Econ 56:27-37

Niraula RR, Pokharel BK (2016) Community forest management as climate change adaptation measure in Nepal's Himalaya. In: Salzmann N, Huggel C, Nussbaumer S, Ziervogel G (eds) Climate change adaptation strategies - an upstream-downstream perspective. Springer, Cham, p 101-120

O'Neill AR, Badola HK, Dhyani PP, Rana SK (2017) Integrating ethnobiological knowledge into biodiversity conservation in the Eastern Himalayas. J Ethnobiol Ethnomed 13(1):1-4
Oakley E, Momsen JH (2007) Women and seed management: a study of two villages in Bangladesh. Singap J Tropical Geogr 28 (1):90-106

Pandey SS, Maraseni TN, Reardon-Smith K, Cockfield G (2017) Analysing foregone costs of communities and carbon benefits in small scale community based forestry practice in Nepal. Land Use Policy 69:160-166

Pant N, Pandey N (2007) Introducing JFM to rural women of Kumaon hills-a case study. Indian Forester 133(12):1690-1694

Persha L, Agrawal A, Chhatre A (2011) Social and ecological synergy, local rulemaking, forest livelihoods, and biodiversity conservation. Science 331(6024):1606-1608

Porter-Bolland L, Ellis EA, Guariguata MR, Ruiz-Mallén I, NegreteYankelevich S, Reyes-García V (2012) Community managed forests and forest protected areas, An assessment of their conservation effectiveness across the tropics. For Ecol Manag 268:6-17

Rai SC (2005) Apatani paddy-cum-fish cultivation: an indigenous hill farming system of North-East India. Indian J Traditional Knowl 4 (1):65-71

Rai SC (2007) Traditional ecological knowledge and communitybased natural resource management in northeast India. J Mt Sci 4 (3): $248-258$

Ramphele M (2004) Women's indigenous knowledge: building bridges between the traditional and modern. In: The World Bank (ed.), Indigenous knowledge: local pathways to global development. The World Bank, Washington, DC, pp 13-17

Rao KS, Maikhuri RK, Sen KK, Das AK, Semwal RL, Singh K, Saxena KG (2005) Soil fertility management in settled farming systems of Himalaya. In: Ramakrishnan PS, Saxena KG, Swift MJ, Rao KS, Maikhuri RK Eds Soil biodiversity, ecological processes and landscape management. Oxford and IBH Publishing Co Pvt. Ltd, New Delhi, p 243-276

Rawal RS, Bhatt ID, Chandra Sekar K, Nandi SK eds. (2013) The Himalayan biodiversity: richness, representativeness, uniqueness and life support values. G.B. Pant Institute of Himalayan Environment and Development (GBPIHED), Kosi-Katarmal, Almora, Uttarakhand, India, p 84

Rawal RS, Negi VS, Bhatt ID (2021) Changing Outlook on Harnessing Biodiversity Values-A Special Focus on Indian Himalaya. Journal of Graphic Era University 9(1):55-82

Rawat S, Jugran A, Giri L, Bhatt ID, Rawal RS (2011) Assessment of antioxidant properties in fruits of Myrica esculenta: A popular wild edible species in Indian Himalayan region. Evidence-Based complementary and alternative medicine 2011:1-8

Ray A, Ray R, Sreevidya EA (2020) How many wild edible plants do we eat - their diversity, use, and implications for sustainable food system: an exploratory analysis in India. Front Sustain Food Syst 4:56

Rodger WA, Panwar HS, Mathur VB (2002) Wildlife protected area network in India: a review. Wildlife Institute of India, 1-51

Roosta RA, Moghaddasi R, Hosseini SS (2017) Export target markets of medicinal and aromatic plants. J Appl Res Medicinal Aromat Plants 7:84-88

Samant SS, Butola JS, Sharma A (2007) Assessment of diversity, distribution, conservation status and preparation of management plan for medicinal plants in the catchment area of parbati hydroelectric project stage-III in Northwestern Himalaya. J Mt Sci 4(1):034-056

Sarkar S, Menon V, Kumar S (2020) Reducing stress among medical students: a qualitative study of students' perspectives. Indian J Psychiatry 62(2):198

Saxena KG, Maikhuri RK, Rao KS (2005) Changes in agricultural biodiversity: implications for sustainable livelihood in the Himalaya. J Mt Sci 2(1):23 
Schmink M, Gómez-García MA (2015) Under the canopy: gender and forests in Amazonia. Occasional paper 121. Center for International Forestry Research (CIFOR), Bogor, Indonesia

Semwal RL, Maikhuri RK (2015) Valuing traditional agrobiodiversity for sustainable development in Uttarakhand. Ecosystem Services and its Mainstreaming in Development Planning Process, 92-114

Sen A (1997) Human capital and human capability. World Dev 25 (12):1959-1961

Shahidullah AK, Haque CE (2010) Linking medicinal plant production with livelihood enhancement in Bangladesh: Implications of a vertically integrated value chain. The Journal of Transdisciplinary Environmental Studies 9(2):1-18

Shahidullah AK, Haque CE (2015) Medicinal plants conservation strategies for primary-healthcare and livelihood at local level: an examination of initiatives in South Asia. In: Medicinal and aromatic plants of the world. Springer, Dordrecht, pp 383-402

Sharma S, Devi R (2014) Sacred groves: traditional way of conserving plant diversity in Block Bhalwal of Jammu District (J\&K). Int J Sci Res (IJSR) 3(2):239-242

Sharma S, Kumar R (2020) Sacred groves of India: repositories of a rich heritage and tools for biodiversity conservation. J Forest Res 9:1-8

Sillitoe P (1998) The development of indigenous knowledge: a new applied anthropology. Curr Anthropol 39(2):223-252

Singh H, Husain T, Agnihotri P (2010) Haat Kali sacred grove, central Himalaya, Uttarakhand. Curr Sci 98(3):298

Singh H, Husain T, Agnihotri P, Pande PC, Khatoon S (2014) An ethnobotanical study of medicinal plants used in sacred groves of Kumaon Himalaya, Uttarakhand, India. J Ethnopharmacol 154 (1):98-108

Singh L, Bhatt ID, Negi VS, Nandi SK, Rawal RS, Bisht AK (2021) Population status, threats, and conservation options of the orchid Dactylorhiza hatagirea in Indian Western Himalaya. Regional Environ Change 21(2):1-16

Singh S, Bhat JA, Malik ZA, Youssouf M, Bussmann RW, Kunwar RM (2019) Sacred groves in Western Himalaya, India: community-managed nature refuges for conservation of biodiversity and culture. Ethnobot Res Appl 18:1-21

Singh S, Youssouf M, Malik ZA, Bussmann RW (2017) Sacred groves: myths, beliefs, and biodiversity conservation-a case study from Western Himalaya, India. Int J Ecol 2017. https://doi. org/10.1155/2017/3828609

Somanathan E (1991) Deforestation, property rights and incentives in Central Himalaya. Economic Political Wkly 26(4):37-46
Somanathan E, Prabhakar R, Mehta BS (2009) Decentralization for cost-effective conservation. Proc Natl Acad Sci 106 (11):4143-4147

Stobdan T, Dolkar P, Chaurasia OP, Kumar B (2017) Seabuckthorn (Hippophae rhamnoides L.) in trans-Himalayan Ladakh. India Def Life Sci J 2(1):46-53

Sundriyal M, Sundriyal RC (2003) Underutilized edible plants of the Sikkim Himalaya: need for domestication. Curr Sci 85 (6):731-736

Thakur S, Negi VS, Pathak R, Dhyani R, Durgapal K, Rawal RS (2020) Indicator based integrated vulnerability assessment of community forests in Indian west Himalaya. Forest Ecology and Management 457:117674

Thapliyal J (2013) Van panchayats script a success story. Jharkhand Panchayat Women Resource Centre. http//jpwrc4.blogspot.com/ 2013/01/

UNESCO (2016) Education for people and planet: creating sustainable futures for all. Global education monitoring report. UNESCO, Paris

Upadhyay KK, Japang B, Singh NS, Tripathi SK (2019) Status and socio-ecological dimensions of sacred groves in Northeast India. J Appl Nat Sci 11(3):590-595

Upreti BM, Tewari LM (2020) Conservation of rare plant species in Thal Kedar Sacred Forest of Pithoragarh, Kumaun Himalaya Uttarakhand. Indian J Nat Sci 10(60):19752-19756

Vandebroek I, Picking D, Tretina J, West J, Grizzle M, Sweil D, Green U, Lindsay D (2021) Root tonics and resilience: building strength, health, and heritage in Jamaica. Front Sustain Food Syst $5: 42$

Vasan S, Kumar S (2006) Situating conserving communities in their place: political economy of Kullu Devban. Conserv Soc $1: 325-346$

Vidyarthi S, Samant SS, Sharma P (2013) Traditional and indigenous uses of medicinal plants by local residents in Himachal Pradesh, North Western Himalaya, India. Int J Biodivers Sci, Ecosyst Serv Manag 9(3):185-200

Wangchuk S, Phuntsho S, Wangdi T (2018) Management issues in community forests management, a case from Bumthang, Bhutan. For Trees Livelihood 27(1):54-60

World Health Organization (2015) Connecting global priorities: biodiversity and human health. World Health Organization and Secretariat of the Convention on Biological Diversity, p. 345

Zardhari V (2000) Barah anaaj. twelve food grains: traditional mixed farming system'. LEISA INDIA 2(3):25 